\title{
Microbial Biodiesel Production by Direct Transesterification of Rhodotorula glutinis Biomass
}

\author{
I-Ching Kuan, Wei-Chen Kao, Chun-Ling Chen and Chi-Yang Yu * \\ Department of Bioengineering, Tatung University, Taipei 10452, Taiwan; iching@ttu.edu.tw (I.-C.K.); \\ weijen0219@gmail.com (W.-C.K.); jojogigi38@gmail.com (C.-L.C.) \\ * Correspondence: chrisyu@ttu.edu.tw; Tel.: +886-2-2182-2928 (ext. 6330)
}

Received: 8 March 2018; Accepted: 19 April 2018; Published: 24 April 2018

\begin{abstract}
Background: Lipids derived from oleaginous microbes have become promising alternative feedstocks for biodiesel. This is mainly because the lipid production rate from microbes is one to two orders of magnitude higher than those of energy crops. However, the conventional process for converting these lipids to biodiesel still requires a large amount of energy and organic solvents; (2) Methods: In this study, an oleaginous yeast, Rhodotorula glutinis, was used for direct transesterification without lipid pre-extraction to produce biodiesel, using sulfuric acid or sodium hydroxide as a catalyst. Such processes decreased the amount of energy and organic solvents required simultaneously; (3) Results: When $1 \mathrm{~g}$ of dry $R$. glutinis biomass was subject to direct transesterification in $20 \mathrm{~mL}$ of methanol catalyzed by $0.6 \mathrm{M} \mathrm{H}_{2} \mathrm{SO}_{4}$ at $70{ }^{\circ} \mathrm{C}$ for $20 \mathrm{~h}$, the fatty acid methyl ester (FAME) yield reached $111 \%$. Using the same amount of biomass and methanol loading but catalyzed by $1 \mathrm{~g} / \mathrm{L} \mathrm{NaOH}$ at $70{ }^{\circ} \mathrm{C}$ for $10 \mathrm{~h}$, the FAME yield reached $102 \%$. The acid-catalyzed process showed a superior moisture tolerance; when the biomass contained 70\% moisture, the FAME yield was $43 \%$ as opposed to $34 \%$ of the base-catalyzed counterpart; (4) Conclusions: Compared to conventional transesterification, which requires lipid pre-extraction, direct transesterification not only simplifies the process and shortens the reaction time, but also improves the FAME yield.
\end{abstract}

Keywords: biodiesel; direct transesterification; Rhodotorula glutinis; single cell oil

\section{Introduction}

Biodiesel is one of the most promising renewable fuels in transportation. It can be used as a drop-in replacement fuel for existing diesel vehicles and boiler engines without major modifications. It is also compatible with current fuel infrastructure [1]. Biodiesel is defined as the fatty acid, alkyl monoesters, derived from renewable feedstocks such as vegetable oils, animal fats, and waste cooking oil. Compared to conventional petrodiesel, biodiesel is highly degradable, non-toxic, and cleaner in exhaust emissions, with the exception of $\mathrm{NO}_{x}$ [2]. The combustion properties of biodiesel are similar to those of petroleum diesel.

Currently, commercial biodiesel is produced by the transesterification of plant oils with short-chain alcohols, using alkaline catalysts such as $\mathrm{NaOH}$ and $\mathrm{KOH}$; most of these plant oils are edible, including rapeseed, sunflower, palm, and soybean oil [3]. The biodiesel derived from these oils (first generation biodiesel) has two major drawbacks: (1) the high cost of feedstocks renders biodiesel unable to compete commercially with petrodiesel [4]; (2) the utilization of these edible plants for fuel production may endanger the world's food supply [5]. These problems led to the development of the second generation which mainly utilizes non-edible plant oils such as jatropha, jojoba, and waste cooking oil [6]. However, the supply of these non-edible oils is not likely to meet the global demand for biodiesel. Recently, the use of oil-accumulating microbes as feedstocks for biodiesel production has 
drawn a lot of attention [7]; the biodiesel derived from these oleaginous microalgae, bacteria, yeasts, and fungi is commonly referred to as the third-generation.

These microbial lipids, also known as single cell oils (SCO), have certain advantages over oils derived from plants. Firstly, these oleaginous microbes can be cultivated all year round with suitable substrates on non-arable lands; secondly, the oil production rate is one to two orders of magnitude higher than those of conventional energy crops [8]. In addition, the lipid compositions of many oleaginous microbes are not too different from those of vegetable oils [9]. This suggests that the fuel properties of biodiesel derived from microbial origins should be similar to those derived from vegetables oils. Among the oleaginous microbes, microalgae have been extensively studied for their potential as alternative feedstocks for biodiesel. Microalgae are mostly phototrophic and capable of accumulating a large amount of biomass and lipids rapidly [10]. Although microalgae are very effective in producing SCO, if grown photo synthetically, they require a large area of land to be cultivated, and are subject to daily and seasonal variations $[9,10]$. Compared to microalgae, oleaginous yeasts could be a better alternative for the production of SCO. The growth rates of these yeasts are faster than those of microalgae; the duplication time could be less than $1 \mathrm{~h}$ in certain cases [11]. Unlike phototrophic microalgae, the growth of oleaginous yeasts is not affected by the variation in weather and sunlight and is less prone to contamination by other microorganisms. Several yeasts are known for their ability to accumulate SCO, such as Cryptococcus curvatus, Lipomyces starkeyi, Rhodosporidium toruloides, and Rhodotorula glutinis [12]. R. glutinis caught our attention as an ideal SCO-producing strain because it could be cultivated with a variety of low cost carbon sources such as crude glycerol [13] and lignocellulosic biomass hydrolysate [14]. R. glutinis is also very effective in accumulating SCO with oil content of up to $72 \%$ [9]. R. glutinis is also capable of synthesizing carotenoids including $\beta$-carotene, torulene, and torularhodin [15]; the composition of these carotenoids depends on the cultivation conditions.

The conventional process for converting yeast SCO to biodiesel includes the following steps in this order: cell disruption, oil extraction, separation and transesterification. In order to decrease the energy expenditure and the amount of solvents used in these steps, many researchers combine the aforementioned steps into one, which is usually described as direct transesterification [16]. The simplified process reduces the overall high cost of biodiesel derived from microbial origins. A fatty acid methyl esters (FAME) yield of up to $98 \%$ was reached by direct transesterification of dry $R$. toruloides biomass catalyzed by either $\mathrm{H}_{2} \mathrm{SO}_{4}$ or $\mathrm{HCl}$ [17]. Using the same dry biomass, a similar yield was also obtained by direct transesterification using $\mathrm{NaOH}$ [18].

In this work, dry R. glutinis biomass was converted to FAME by direct transesterification with either acidic or basic catalysts. The effects of catalyst amount, reaction temperature, incubation time, and methanol loading on FAME yield were studied. In order to evaluate the feasibility of using wet biomass directly, the influences of moisture content on the FAME yield were also examined. Finally, under optimized reaction conditions, the yields and FAME compositions from direct transesterification were compared with those from the conventional processes.

\section{Results and Discussion}

\subsection{Effect of Catalyst Concentration on Transesterification}

The average biomass concentration of $R$. glutinis from fermentation was $16 \pm 5 \mathrm{~g} / \mathrm{L}$, with a lipid content of $39 \pm 6 \%$. Simple calculation revealed that $1 \mathrm{~g}$ of FAME is expected for $1 \mathrm{~g}$ of microbial lipid under complete transesterification. Thus the highest theoretical yield is $100 \%$.When 0.1 and $0.2 \mathrm{~g} / \mathrm{L}$ $\mathrm{NaOH}$ were used as catalysts, no FAME product was detected (Figure 1a). The added $\mathrm{NaOH}$ could be consumed by the saponification side reaction because there was an excess of yeast lipids. The FAME yield increased to $18 \%$ when the catalyst concentration was $0.5 \mathrm{~g} / \mathrm{L}$; the highest FAME yield of $94 \%$ was observed with $1 \mathrm{~g} / \mathrm{L} \mathrm{NaOH}$. However, the FAME yield started to decrease rapidly as the catalyst concentration increased further. No FAME was observed with $4 \mathrm{~g} / \mathrm{L} \mathrm{NaOH}$; a high alkaline catalyst 
concentration may facilitate saponification, thus leading to this low FAME yield [19]. Our results indicated that only a narrow range of $\mathrm{NaOH}$ concentration was suitable for FAME production. Similar results were observed by others using dry $R$. toruloides biomass as a feedstock [18]. The $\mathrm{NaOH}$ concentration of $1 \mathrm{~g} / \mathrm{L}$ was selected for later experiments.

When $0.05 \mathrm{M} \mathrm{H}_{2} \mathrm{SO}_{4}$ was used as a catalyst, the FAME yield was only $46 \%$ (Figure $1 \mathrm{~b}$ ). The FAME yield increased with the concentration of $\mathrm{H}_{2} \mathrm{SO}_{4}$, and the highest FAME yield of $103 \%$ was observed with $0.6 \mathrm{M} \mathrm{H}_{2} \mathrm{SO}_{4}$. However, a further increase in the $\mathrm{H}_{2} \mathrm{SO}_{4}$ concentration to $0.8 \mathrm{M}$ led to a decrease in FAME yield; a similar observation was made by others using a dry $R$. toruloides biomass as a feedstock, and the decrease in FAME yield was explained as a result of side reactions such as polymerization under harsh conditions [17]. The transesterification reaction mixture appeared orange when $\mathrm{H}_{2} \mathrm{SO}_{4}$ concentration was below $0.1 \mathrm{M}$, but the color changed to light yellow as the catalyst concentration increased further; the color change may be due to the oxidation of the caroteinoids present in the biomass [20]. The $\mathrm{H}_{2} \mathrm{SO}_{4}$ concentration of $0.6 \mathrm{M}$ was selected for later experiments.

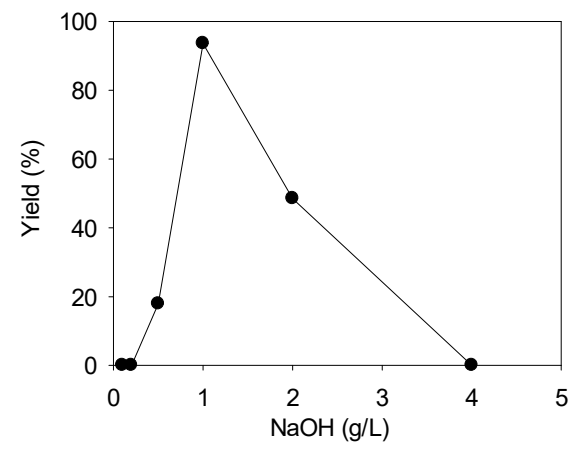

(a)

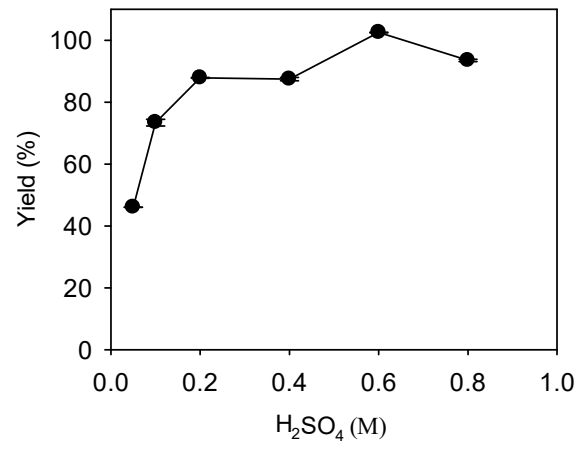

(b)

Figure 1. The effect of catalyst concentration on fatty acid methyl ester (FAME) yield. (a) $\mathrm{NaOH}$; (b) $\mathrm{H}_{2} \mathrm{SO}_{4}$. For both catalysts, direct transesterification on $1 \mathrm{~g}$ of dry $R$. glutinis biomass was carried out with a methanol loading of 1:20 (biomass: methanol, $w / v$ ) at $70{ }^{\circ} \mathrm{C}$ for $15 \mathrm{~h}$. Data were obtained by averaging three individual measurements and the standard deviations were indicated with error bars.

\subsection{Effect of Reaction Time and Temperature on Transesterification}

The FAME yield obtained by $\mathrm{NaOH}$ catalysis was only $49 \%$ after $2 \mathrm{~h}$ of incubation, while increasing dramatically up to a yield of $102 \%$ after $10 \mathrm{~h}$ of incubation (Figure 2). Further extension of the reaction time did not improve the yield, indicating that the reaction reached completion after $10 \mathrm{~h}$. When $\mathrm{H}_{2} \mathrm{SO}_{4}$ was used as a catalyst, the FAME yield increased with the reaction time of up to $20 \mathrm{~h}$ with a yield of $111 \%$. More FAME was formed than the available lipid which could be explained by the following reasons: (1) The lipid content within the biomass was underestimated; (2) some phopholipids were also converted to FAME [21,22]. Further increase in the reaction time beyond $20 \mathrm{~h}$ did not improve the FAME yield. For later experiments, the reaction times of 10 and $20 \mathrm{~h}$ were used for $\mathrm{NaOH}$ and $\mathrm{H}_{2} \mathrm{SO}_{4}$ catalysts, respectively.

With a $10 \mathrm{~h}$ reaction time and $\mathrm{NaOH}$ as a catalyst; the FAME yields at 50 and $60^{\circ} \mathrm{C}$ were only $61 \%$ and $94 \%$, respectively; even increasing the reaction duration up to $20 \mathrm{~h}$ did not enhance the FAME yield. Thus, $70{ }^{\circ} \mathrm{C}$ was optimal for FAME production catalyzed by $\mathrm{NaOH}$. A similar observation was also obtained with catalysis by $\mathrm{H}_{2} \mathrm{SO}_{4}$. A previous study reported an optimal temperature of $50{ }^{\circ} \mathrm{C}$ for converting the dry biomass of oleaginous $R$. toruloides directly to biodiesel within a lidded test tube [18]. The difference in the optimal reaction temperature might be attributed to a different reaction setup. In later experiments, for both $\mathrm{NaOH}$ and $\mathrm{H}_{2} \mathrm{SO}_{4}$, a reaction temperature of $70{ }^{\circ} \mathrm{C}$ was used. 


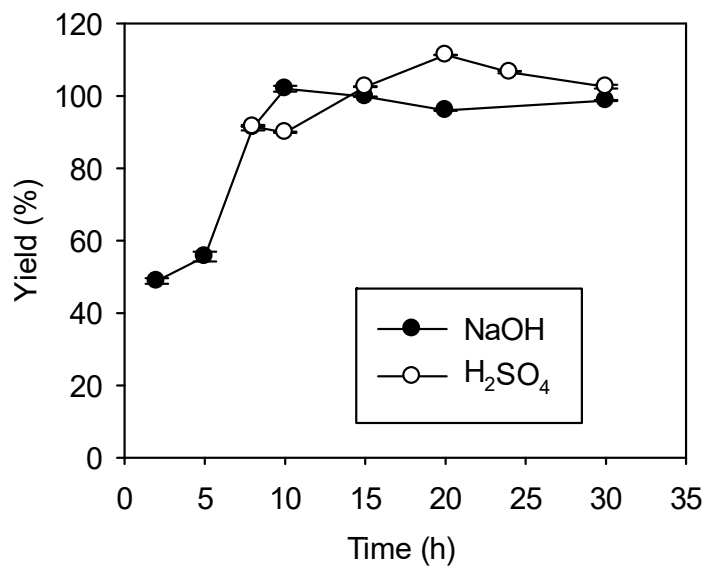

Figure 2. The effect of reaction time on FAME yield. Direct transesterification on $1 \mathrm{~g}$ of dry R. glutinis biomass was carried out with a methanol loading of 1:20 (biomass: methanol, $w / v$ ) at $70^{\circ} \mathrm{C}$ using $1 \mathrm{~g} / \mathrm{L}$ $\mathrm{NaOH}$ or $0.6 \mathrm{M} \mathrm{H}_{2} \mathrm{SO}_{4}$ as a catalyst. Data were obtained by averaging three individual measurements and the standard deviations were indicated with error bars.

\subsection{Effect of Methanol Loading on Transesterification}

Methanol serves as one of the reactants and also acts as a solvent to weaken and disrupt the cell walls [23]. The effect of methanol loading on transesterification is shown in Figure 3. When $\mathrm{NaOH}$ was used as a catalyst, almost no FAME was formed with a biomass to methanol ratio $(w / v)$ of 1:10; this could be because themethanol loading is insufficient to disrupt the cell walls effectively. When the biomass to methanol ratio was increased to 1:20, the highest yield of $102 \%$ was obtained. Nevertheless, the yield started to decrease as the ratio was further increased; similar results were also observed by others [24]. One possible explanation for the decreased yield at high methanol loading is that excess methanol dilutes the biomass and catalyst concentrations, thus giving rise to a lower conversion [18,24]. On the other hand, when $\mathrm{H}_{2} \mathrm{SO}_{4}$ was employed as a catalyst, the methanol loading had little influence on the FAME yield within the range we studied. For both catalysts, a biomass to methanol ratio $(w / v)$ of 1:20 was used for later experiments.

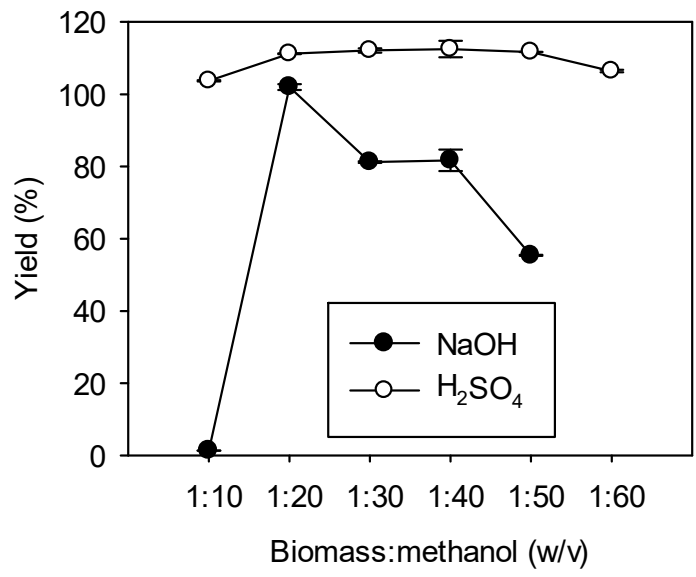

Figure 3. The effect of methanol loading on transesterification. Direct transesterification on $1 \mathrm{~g}$ of dry R. glutinis biomass was carried out at $70{ }^{\circ} \mathrm{C}$ with $1 \mathrm{~g} / \mathrm{L} \mathrm{NaOH}$ and $0.6 \mathrm{M} \mathrm{H}_{2} \mathrm{SO}_{4}$ for 10 and $20 \mathrm{~h}$, respectively. Data were obtained by averaging three individual measurements and the standard deviations were indicated with error bars. 


\subsection{Effect of Moisture on Transesterification}

In an esterification reaction, the moisture content should be minimized because the presence of water favors the generation of free fatty acids from the hydrolysis of triglycerides, thus enhancing the degree of saponification and lowering the FAME yield. Previous studies on the transesterification of vegetable oils have shown that the presence of water even at very low concentrations has a detrimental effect on the FAME yield [25]. To determine the effect of moisture content on the FAME yield, various amounts of water were added back to $1 \mathrm{~g}$ of dry biomass; the moisture content was defined by the following equation:

$$
\begin{gathered}
\text { moisture content }(\%)=\text { amount of added water }(\mathrm{g}) /(\text { amount of added water }(\mathrm{g})+ \\
1 \mathrm{~g} \text { of biomass })
\end{gathered}
$$

Using $\mathrm{NaOH}$ as a catalyst, the FAME yield was decreased with an increase in the moisture content (Figure 4); the FAME yield was 34\% when the biomass contained $70 \%$ moisture. Our results were quite different from those reported for $R$. toruloides (also using $\mathrm{NaOH}$ as a catalyst), which showed that there was almost no formation of FAME with moisture content above 10\% [18]. In the case of $\mathrm{H}_{2} \mathrm{SO}_{4}$, the process tolerated moisture fairly well up to $50 \%$. However, the FAME yield decreased rapidly to $85 \%$ and $43 \%$ when the biomass contained $60 \%$ and $70 \%$ moisture, respectively. Similar results were obtained by others using dry microalgae biomass, Chaetoceros gracilis, as a feed stock with a higher methanol loading of 1:40 [21]. We have also examined the feasibility of using a wet $R$. glutinis biomass collected from centrifugation without drying (the moisture content was $72 \%$ ) for direct transesterification. However, this included a heating step at $80^{\circ} \mathrm{C}$ for $10 \mathrm{~min}$ before centrifugation. Consequently, the FAME yield could reach 73\%. Yellapu et al. reported that the yield could be further improved by pre-treating the wet biomass with surfactants such as $\mathrm{N}$-lauroyl sarcosine, and the reaction time may also be shortened by carrying out the reaction under sonication [26].

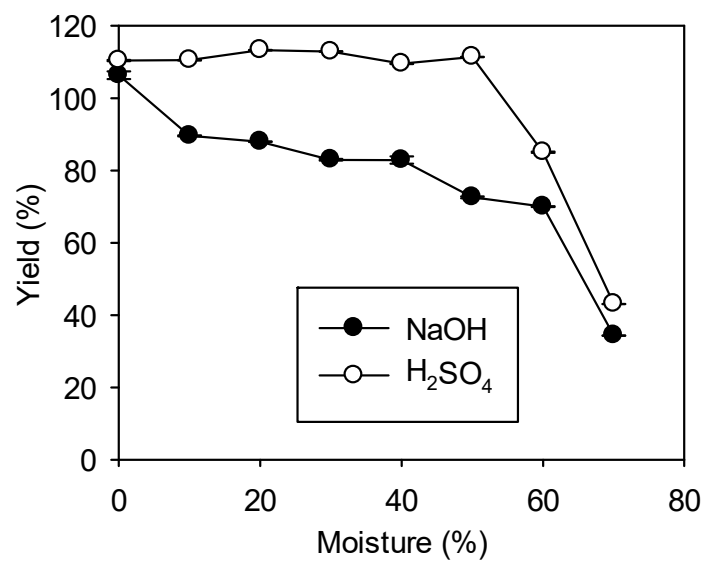

Figure 4. The effect of moisture on FAME yield. Direct transesterification on $1 \mathrm{~g}$ of dry R. glutinis biomass was carried out at $70{ }^{\circ} \mathrm{C}$ with $1 \mathrm{~g} / \mathrm{L} \mathrm{NaOH}$ and $0.6 \mathrm{M} \mathrm{H}_{2} \mathrm{SO}_{4}$ for 10 and $20 \mathrm{~h}$, respectively. A methanol loading of 1:20 (biomass: methanol, $w / v$ ) was used for both catalysts. Data were obtained by averaging three individual measurements and the standard deviations were indicated with error bars.

\subsection{Comparison of Yields and Compositions of FAME Derived from Different Transesterification Methods}

The yields and compositions of FAME produced by different transesterification methods are listed in Table 1. The conventional methods resulted in lower FAME yields of $78 \%$ and $85 \%$ using $\mathrm{NaOH}$ and $\mathrm{H}_{2} \mathrm{SO}_{4}$ as catalysts, respectively; the acidic method had a yield similar to that of the previous report $(81 \%)$, using the same biomass [27]. Direct transesterification, regardless of the catalyst used, resulted in significantly higher yields in a shorter time (approximately $4 \mathrm{~h}$ less) than conventional methods, which involved cell disruption, lipid extraction, and transesterification in that 
order. For direct transesterification, the compositions of FAME obtained with either catalyst were almost the same; the oleic acid methyl ester was the dominant FAME, followed by linoleic, and then palmitic acid methyl ester. However, a previous report showed that the FAME composition was catalyst dependent, especially for oleic and linolenic acid methyl esters [18]. The content of linoleic acid methyl ester from direct transesterification was about $20 \%$ higher than the linoleic acid content of R. glutinis cultured with glycerol as a carbon source [13,14]. The higher amount of linoleic acid methyl ester was explained by the fact that some FAME was derived from the phospholipids in the cell membrane [22,23]. When conventional methods were used, the linoleic acid methyl ester was the dominant FAME, followed by oleic acid methyl ester instead.

Table 1. Yields and compositions of FAME derived from R. glutinis using different transesterification methods.

\begin{tabular}{lccccccc}
\hline \multirow{2}{*}{\multicolumn{1}{c}{ Method }} & $\begin{array}{c}\text { FAME Yield } \\
\mathbf{( \% )}^{\mathbf{a}}\end{array}$ & \multicolumn{5}{c}{ FAME Composition (\%) } \\
\cline { 3 - 7 } & & $\mathbf{C 1 6 : 0}$ & $\mathbf{C 1 6 : 1}$ & $\mathbf{C 1 8 : 0}$ & $\mathbf{C 1 8 : 1}$ & $\mathbf{C 1 8 : 2}$ & $\mathbf{C 1 8 : 3}$ \\
\hline Direct acid-catalyzed & $111.0 \pm 0.1$ & 16.8 & 0.7 & 4.1 & 42.2 & 33.8 & 2.5 \\
Direct base-catalyzed & $102.0 \pm 0.8$ & 18.8 & 0.7 & 4 & 41.1 & 32.9 & 2.6 \\
Conventional acid-catalyzed $^{\mathrm{b}}$ & $85.2 \pm 0.9$ & 18.1 & 1.6 & 3 & 33.3 & 41.1 & 4.1 \\
Conventional base-catalyzed $^{\mathrm{c}}$ & $77.9 \pm 0.7$ & 21 & 1 & 2.5 & 30.5 & 41.2 & 3.7 \\
\hline
\end{tabular}

${ }^{a}$ Data were obtained by averaging three individual measurements. ${ }^{b}$ The lipid was first extracted as described in Methods (Total lipid analysis) except that $1 \mathrm{~g}$ of dry biomass was used and reagents required were scaled-up accordingly. Transesterification of extracted lipid was carried out with $0.6 \mathrm{M} \mathrm{H}_{2} \mathrm{SO}_{4}$ for $20 \mathrm{~h}$ at $70{ }^{\circ} \mathrm{C}$, using a methanol loading of 1:20 (biomass: methanol, $w / v$ ). ${ }^{\mathrm{C}}$ The lipid was first extracted as described in Methods (Total lipid analysis) except that $1 \mathrm{~g}$ of dry biomass was used and the reagents required were scaled-up accordingly. The transesterification of extracted lipid was carried out with $1 \mathrm{~g} / \mathrm{L} \mathrm{NaOH}$ for $10 \mathrm{~h}$ at $70{ }^{\circ} \mathrm{C}$, using a methanol loading of 1:20 (biomass: methanol, $w / v$ ).

\section{Materials and Methods}

\subsection{Microorganism and Medium}

The seed medium for culturing R. glutinis BCRC (Bioresource Collection and Research Center, Hsinchu, Taiwan) 22,360 contained $3 \mathrm{~g}$ of yeast extract, $3 \mathrm{~g}$ of malt extract, $5 \mathrm{~g}$ of peptone, and $10 \mathrm{~g}$ of dextrose per liter. The fermentation medium contained $80 \mathrm{~g}$ of crude glycerol (Yu-Hwa Biodiesel Company, Changhua, Taiwan), $2 \mathrm{~g}$ of yeast extract, $2 \mathrm{~g}$ of $\left(\mathrm{NH}_{4}\right)_{2} \mathrm{SO}_{4}, 1 \mathrm{~g}$ of $\mathrm{KH}_{2} \mathrm{PO}_{4}, 0.5 \mathrm{~g}$ of $\mathrm{MgSO}_{4} \cdot 7 \mathrm{H}_{2} \mathrm{O}, 0.1 \mathrm{~g}$ of $\mathrm{CaCl}_{2}$, and $0.1 \mathrm{~g}$ of $\mathrm{NaCl}$ per liter. The crude glycerol, dark brown in color and slightly viscous, was used directly without any pretreatment or purification.

\subsection{Production of Biomass}

Under aerobic conditions, $300 \mathrm{~mL}$ of seed culture was prepared in a seed medium after a 24-h incubation at $24^{\circ} \mathrm{C}$ with orbital shaking at $150 \mathrm{rpm}$. The seed culture was inoculated into a 5-L stirred-tank fermentor (BIOSTAT ${ }^{\circledR}$ A plus, Sartorius, Gottingen, Germany) containing 2.7 L of fermentation medium ( $3 \mathrm{~L}$ working volume). The $\mathrm{pH}$ was maintained at 5.5 by automatically feeding 1.0 N NaOH or $1.0 \mathrm{~N} \mathrm{HCl}$ solution into the medium. The fermentor was operated at $24^{\circ} \mathrm{C}$ with dissolved oxygen controlled at $30, \pm 2 \%$ of the saturation level. The agitation during the process was limited to a range from 200 to $400 \mathrm{rpm}$ to avoid potential damage resulting from high shear force. The biomass was harvested after $72 \mathrm{~h}$ of incubation by centrifugation at $12,021 \times g$, and then the pellets were washed with deionized water to remove any residual fermentation medium. The biomass was stored at $-80{ }^{\circ} \mathrm{C}$ for $24 \mathrm{~h}$ before lyophilized in a Freezemobile $12 \mathrm{XL}$ freeze dryer (Virtis). The dried biomass was stored in a refrigerator for later use.

\subsection{Total Lipid Analysis}

The extraction of lipids from a biomass was modified from the procedure reported by Bligh and Dyer [28]. Fifty milliliters of chloroform/methanol mixture $(2: 1, v / v)$ was mixed with $0.5 \mathrm{~g}$ of finely 
ground powder of dry biomass. The suspension was then subject to ultrasonication with a Misonix XL2020 sonicator for $6 \mathrm{~min}$ on an ice bath; the ultrasonic horn was directly immersed in the suspension and the on/off cycle was set to $60 / 60 \mathrm{~s}$ in order to minimize the heat generated. The suspension was incubated at room temperature for $1 \mathrm{~h}$ on a rocking mixer at $100 \mathrm{rpm}$. The solvent phase was collected by centrifugation at $12,100 \times g$ for $10 \mathrm{~min}$; the biomass was extracted with an additional $30 \mathrm{~mL}$ of chloroform/methanol mixture for $1 \mathrm{~h}$. The combined solvent phase was evaporated at $65^{\circ} \mathrm{C}$ under vacuum (337 mbar), and then the remaining lipid was weighted. The lipid content was defined as below:

$$
\text { lipid content }(\%)=\text { weight of lipid }(\mathrm{g}) / \text { weight of biomass }(\mathrm{g}) \times 100
$$

\subsection{Direct Transesterification}

One gram of dry biomass and various amounts of methanol (biomass to methanol ratio in the range of 1:10 to $1: 60, w / v)$ were added to a $100 \mathrm{~mL}$ round-bottom flask fitted with a condenser. $\mathrm{NaOH}$ (from 0.1 to $4 \mathrm{~g} / \mathrm{L}$ ) or $\mathrm{H}_{2} \mathrm{SO}_{4}$ (from 0.05 to $0.8 \mathrm{M}$ ) dissolved in methanol was used as a catalyst. The suspension was heated at 40 to $70{ }^{\circ} \mathrm{C}$ in a water bath under atmospheric pressure with vigorous mixing for 2 to $30 \mathrm{~h}$, followed by a centrifugation at $12,100 \times \mathrm{g}$ for $10 \mathrm{~min}$ and a collection of the supernatant. The residual biomass was then washed with $10 \mathrm{~mL}$ of $n$-hexane and the washing fraction was collected after centrifugation as described above. The supernatant and the washing fraction were combined and extracted with equal volume of $n$-hexane. The $n$-hexane layer was collected and the solvent was evaporated at $65{ }^{\circ} \mathrm{C}$ under vacuum ( $337 \mathrm{mbar}$ ). The biodiesel product was collected and weighted. The experiments were performed in triplicate; the average from triplicate was plotted in the figures and the standard deviation was indicated with an error bar.

\subsection{Analysis of Fatty Acid Methyl Esters}

The content of FAME in the transesterification product was measured according to the standard of Taiwan, CNS-15051. The biodiesel product was first treated with sodium sulfate followed by centrifugation at $2040 \times g$ for $5 \mathrm{~min}$. Fifty microliters of the treated sample was mixed with $1 \mathrm{~mL}$ of $10 \mathrm{mg} / \mathrm{mL}$ methyl heptadecanoate in hexane as an internal standard. One microliter of the sample was injected into a gas chromatograph (GC-2014, Shimadzu, Kyoto, Japan) equipped with a flame-ionization detector (FID). A BPX70 capillary column $(30 \mathrm{~m} \times 0.25 \mathrm{~mm}$ i.d.; SGE Analytical Science, Ringwood, Australia) with nitrogen as carrier gas was used. The injector and FID temperatures were both set at $250^{\circ} \mathrm{C}$. The oven temperature was initially held at $150{ }^{\circ} \mathrm{C}$ for $30 \mathrm{~s}$ and then increased to $180^{\circ} \mathrm{C}$ at $10^{\circ} \mathrm{C} / \mathrm{min}$, finally to $198^{\circ} \mathrm{C}$ at $1.5^{\circ} \mathrm{C} / \mathrm{min}$. The content of FAME was calculated using the following equation:

$$
\text { FAME content }(\%)=\frac{\sum \mathrm{A}-\mathrm{A}_{\mathrm{EI}}}{\mathrm{A}_{\mathrm{EI}}} \times \frac{\mathrm{C}_{\mathrm{EI}} \times \mathrm{V}_{\mathrm{EI}}}{\mathrm{m}} \times 100
$$

where $\Sigma \mathrm{A}$ is the summation of peak area of all the FAME peaks (from C14:0 to C24:1); $\mathrm{A}_{\mathrm{EI}}$ is the peak area of internal standard, methyl heptadecanoate; $\mathrm{C}_{\mathrm{EI}}$ is the concentration of methyl heptadecanoate, $\mathrm{V}_{\mathrm{EI}}$ is the volume of methyl heptadecanoate, and $\mathrm{m}$ is the mass of the biodiesel sample. The FAME yield was calculated using the following equation:

$$
\text { FAME yield }(\%)=\frac{\text { FAME content }(\%) \times \text { weight of biodiesel }(\mathrm{g})}{\text { lipid content }(\%) \times \text { weight of biomass }(\mathrm{g})} \times 100
$$

\section{Conclusions}

In this study, the oleaginousyeast, R. glutinis, was used for the direct transesterification without lipid pre-extraction to produce FAME. The use of chloroform, a highly toxic organic solvent often applied in lipid extraction, was avoided. The highest FAME yield of $111 \%$ was obtained with $0.6 \mathrm{M}$ $\mathrm{H}_{2} \mathrm{SO}_{4}$ as a catalyst and a methanol loading of 1:20 (biomass to methanol, $w / v$ ), the reaction was carried out at $70{ }^{\circ} \mathrm{C}$ for $20 \mathrm{~h}$. Using the same methanol loading and temperature, a slightly lower yield 
of $102 \%$ was obtained with $1 \mathrm{~g} / \mathrm{L} \mathrm{NaOH}$ after $10 \mathrm{~h}$ of incubation. Although basic catalysts are often avoided because of the potential saponification caused by the free fatty acids present in $\mathrm{SCO}$, the $\mathrm{NaOH}$ catalyst was still able to achieve similar FAME yield in half the reaction time required by the $\mathrm{H}_{2} \mathrm{SO}_{4}$ catalyst. However, the acid-catalyzed direct transesterification tolerates moisture content much better than the base-catalyzed process; thus, the $\mathrm{H}_{2} \mathrm{SO}_{4}$ catalyst is more suitable for wet biomass feedstocks. Compared to conventional transesterification, the direct process is not only simpler, but also improves the FAME yield by $24-29 \%$ with a shorter reaction time and a lower energy consumption. The reaction processes reported in this work simplify for the production of SCO-derived biodiesel and reduce its cost. Our preliminary work also indicates that wet biomass can be used directly as a feedstock with some minor adjustments in reaction conditions, suggesting that further process simplification and cost reduction are possible.

Author Contributions: Chi-Yang Yu and I-Ching Kuan designed the experiments and analyzed the data. Wei-Chen Kao and Chun-Ling Chen performed the experiments using the basic and acidic catalyst, respectively. Chi-Yang Yu and I-Ching Kuan prepared the manuscript. All authors read and approved the final manuscript. All authors contributed equally to this work.

Acknowledgments: We thank Hong-Wei Yen (Department of Chemical and Materials Engineering, Tunghai University, Taiwan) and Yaw-Nan Chang (Department of Biotechnology, National Formosa University, Taiwan) for providing R. glutinis BCRC 22360.This work was supported by the Ministry of Science and Technology (MOST 105-2621-M-036-001-MY2) in Taiwan.

Conflicts of Interest: The authors declare no conflict of interest.

\section{References}

1. Sitepu, I.R.; Garay, L.A.; Sestric, R.; Levin, D.; Block, D.E.; German, J.B.; Boundy-Mills, K.L. Oleaginous yeasts for biodiesel: Current and future trends in biology and production. Biotechnol. Adv. 2014, 32, 1336-1360. [CrossRef] [PubMed]

2. Canakci, M.; Sanli, H. Biodiesel production from various feedstocks and their effects on the fuel properties. J. Ind. Microbiol. Biotechnol. 2008, 35, 431-441. [CrossRef] [PubMed]

3. Fukuda, H.; Kondo, A.; Noda, H. Biodiesel fuel production by transesterification of oils. J. Biosci. Bioeng. 2001, 92, 405-416. [CrossRef]

4. Demirbas, A. Importance of biodiesel as transportation fuel. Energy Policy 2007, 35, 4661-4670. [CrossRef]

5. Escobar, J.C.; Lora, E.S.; Venturini, O.J.; Yáñez, E.E.; Castillo, E.F.; Almazan, O. Biofuels: Environment, technology and food security. Renew. Sustain. Energy Rev. 2009, 13, 1275-1287. [CrossRef]

6. Kulkarni, M.G.; Dalai, A.K. Waste cooking oil-an economical source for biodiesel: A review. Ind. Eng. Chem. Res. 2006, 45, 2901-2913. [CrossRef]

7. Huang, C.; Chen, X.-F.; Xiong, L.; Chen, X.-D.; Ma, L.-L.; Chen, Y. Single cell oil production from low-cost substrates: The possibility and potential of its industrialization. Biotechnol. Adv. 2013, 31, 129-139. [CrossRef] [PubMed]

8. Chen, C.-Y.; Yeh, K.-L.; Aisyah, R.; Lee, D.-J.; Chang, J.-S. Cultivation, photobioreactor design and harvesting of microalgae for biodiesel production: A critical review. Bioresour. Technol. 2011, 102, 71-81. [CrossRef] [PubMed]

9. Meng, X.; Yang, J.; Xu, X.; Zhang, L.; Nie, Q.; Xian, M. Biodiesel production from oleaginous microorganisms. Renew. Energy 2009, 34, 1-5. [CrossRef]

10. Chisti, Y. Biodiesel from microalgae. Biotechnol. Adv. 2007, 25, 294-306. [CrossRef] [PubMed]

11. Yousuf, A.; Khan, M.R.; Islam, M.A.; Wahid, Z.A.; Pirozzi, D. Technical difficulties and solutions of direct transesterification process of microbial oil for biodiesel synthesis. Biotechnol. Lett. 2017, 39, 13-23. [CrossRef] [PubMed]

12. Ratledge, C.; Cohen, Z. Microbial and algal oils: Do they have a future for biodiesel or as commodity oils? Lipid Technol. 2008, 20, 155-160. [CrossRef]

13. Yen, H.-W.; Zhang, Z. Effects of dissolved oxygen level on cell growth and total lipid accumulation in the cultivation of Rhodotorula glutinis. J. Biosci. Bioeng. 2011, 112, 71-74. [CrossRef] [PubMed] 
14. Yen, H.-W.; Chang, J.-T. Growth of oleaginous Rhodotorula glutinis in an internal-loop airlift bioreactor by using lignocellulosic biomass hydrolysate as the carbon source. J. Biosci. Bioeng. 2015, 119, 580-584. [CrossRef] [PubMed]

15. Kot, A.M.; Błażejak, S.; Kurcz, A.; Gientka, I.; Kieliszek, M. Rhodotorula glutinis—Potential source of lipids, carotenoids, and enzymes for use in industries. Appl. Microbiol. Biotechnol. 2016, 100, 6103-6117. [CrossRef] [PubMed]

16. Cheirsilp, B.; Louhasakul, Y. Industrial wastes as a promising renewable source for production of microbial lipid and direct transesterification of the lipid into biodiesel. Bioresour. Technol. 2013, 142, 329-337. [CrossRef] [PubMed]

17. Liu, B.; Zhao, Z. Biodiesel production by direct methanolysis of oleaginous microbial biomass. J. Chem. Technol. Biotechnol. 2007, 82, 775-780. [CrossRef]

18. Thliveros, P.; Uçkun Kiran, E.; Webb, C. Microbial biodiesel production by direct methanolysis of oleaginous biomass. Bioresour. Technol. 2014, 157, 181-187. [CrossRef] [PubMed]

19. Leung, D.Y.C.; Guo, Y. Transesterification of neat and used frying oil: Optimization for biodiesel production. Fuel Process. Technol. 2006, 87, 883-890. [CrossRef]

20. Boon, C.S.; McClements, D.J.; Weiss, J.; Decker, E.A. Factors influencing the chemical stability of carotenoids in foods. Crit. Rev. Food Sci. Nutr. 2010, 50, 515-532. [CrossRef] [PubMed]

21. Wahlen, B.D.; Willis, R.M.; Seefeldt, L.C. Biodiesel production by simultaneous extraction and conversion of total lipids from microalgae, cyanobacteria, and wild mixed-cultures. Bioresour. Technol. 2011, 102, 2724-2730. [CrossRef] [PubMed]

22. Vicente, G.; Bautista, L.F.; Rodríguez, R.; Gutiérrez, F.J.; Sádaba, I.; Ruiz-Vázquez, R.M.; Torres-Martínez, S.; Garre, V. Biodiesel production from biomass of an oleaginous fungus. Biochem. Eng. J. 2009, 48, $22-27$. [CrossRef]

23. Zhang, X.; Yan, S.; Tyagi, R.D.; Surampalli, R.Y.; Valéro, J.R. Ultrasonication aided in-situ transesterification of microbial lipids to biodiesel. Bioresour. Technol. 2014, 169, 175-180. [CrossRef] [PubMed]

24. Patil, P.D.; Gude, V.G.; Mannarswamy, A.; Cooke, P.; Munson-McGee, S.; Nirmalakhandan, N.; Lammers, P.; Deng, S. Optimization of microwave-assisted transesterification of dry algal biomass using response surface methodology. Bioresour. Technol. 2011, 102, 1399-1405. [CrossRef] [PubMed]

25. Canakci, M.; Van Gerpen, J. Biodiesel production via acid catalysis. Trans. ASAE 1999, 42, $1203-1210$. [CrossRef]

26. Yellapu, S.K.; Kaur, R.; Tyagi, R.D. Detergent assisted ultrasonication aided in situ transesterification for biodiesel production from oleaginous yeast wet biomass. Bioresour. Technol. 2017, 224, 365-372. [CrossRef] [PubMed]

27. Dai, C.-C.; Tao, J.; Xie, F.; Dai, Y.-J.; Zhao, M. Biodiesel generation from oleaginous yeast Rhodotorula glutinis with xylose assimilating capacity. Afr. J. Biotechnol. 2007, 6, 2130-2134.

28. Bligh, E.G.; Dyer, W.J. A rapid method of total lipid extraction and purification. Can. J. Biochem. Physiol. 1959, 37, 911-917. [CrossRef] [PubMed]

(C) 2018 by the authors. Licensee MDPI, Basel, Switzerland. This article is an open access article distributed under the terms and conditions of the Creative Commons Attribution (CC BY) license (http://creativecommons.org/licenses/by/4.0/). 